\title{
Enhancing lean supply chain through traffic light quality management system
}

\author{
Md. Mazharul Islam ${ }^{a^{*}}$ and Md. Sadequr Rahman ${ }^{\mathrm{b}}$
}

Institute of Apparel Research and Technology (iART), Bangladesh Knitwear Manufacturers and Exporters Association (BKMEA), Planners Tower, Bangla Motor, Dhaka-1000, Bangladesh

\begin{tabular}{l}
\hline C H R O N I C L E \\
\hline Article history: \\
Received August 12, 2012 \\
Received in revised format \\
3 January 2013 \\
Accepted 30 January 2013 \\
Available online \\
January 302013 \\
\hline Keywords: \\
Lean Manufacturing System \\
Quality Management System \\
(QMS) \\
Traffic Light System \\
Supply Chain Management (SCM) \\
Lean Supply Chain \\
Lead Time
\end{tabular}

\begin{abstract}
A B S T R A C T
Lean is a continuous journey to grow and excel the company. Any company want to develop and cope with the world pace must adopt lean. However, in most of the organizations the management culture or people's mentality is not so good to embrace change. They have predestined mind set where no change is normally allowed. Lean is a cooperative way of working that involves all departments and all personnel to work together in a team for the betterment of the entire company. Without providing fixed solution of any problem it suggests the best way that people willingly accept to do. Lean normally deals with highest quality, shorter lead time and lowest cost. In Bangladesh, most of the garment manufacturing companies are experiencing a massive quality problem. We describe a case where traffic light, a tool of lean quality system was adopted to a garment manufacturing company in Bangladesh. We also provide the charts to contrast the before and after scenario in detail, in order to illustrate the company benefits. After the traffic light system being implemented, the quality status was improved, production capacity was increased; significant days were saved that enhanced the lead time and thus strengthen the supply chain.
\end{abstract}

\section{Introduction}

In the recent time garments sector is becoming more volatile day by day. Garments styles are changing rapidly. However, buyers are more inimical with lead time, quality and cost. They are willing to get higher quality product with at a shortest lead time offering lowest price for it. This is a common phenomenon, which is happening now in the garment sector all over the world. Having the current state of the garment factories and knowing the buyers expectations and requirements, it would be very difficult to survive or to grow. Therefore, quality is becoming a vital key to successful growth of a company. The main objectives of the factories are to tide up to the lead time and the cost. Therefore, it is becoming a crying need for the factories to improve its quality level as well as productivity. The factories should be more efficient to attain the highest productivity level of quality product. Supply chain should be more agile to give quick support to the production lines.

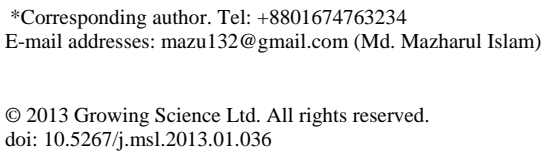


Though the term lean was first coined by USA but it is nothing but the concept of Toyota production system in Japan and the system was basically pioneered by Eiji Toyoda and Taiici Ohno. Ohno (1988) basically tried to eliminate waste by establishing just in time (JIT) and KANBAN production system and ensuring the flow of raw materials to make production flow more strong. Lean manufacturing always focus on the voice of customer. Lean manufacturing see the value of a product or a service in terms of customer requirement. Customers normally evaluate the product or the service by looking at how well this is going to fulfill their requirements. The term 'lean' as Womack and Jones (1990) define it as a system that utilizes a less, in terms of all inputs, to create the same outputs as those created by a traditional mass production system while contributing increased varieties for the end customer. The most common goal of lean manufacturing is to improve quality, eliminate waste, reduce time, and reduce total costs so that the supply chain could be more agile to produce and ship the garments with a shortest lead time.

Lead time is the total time required to order reception, processing, manufacture and to deliver the product to the customer. Christopher (1998) defines lead time as the combination of logistics lead time and the customer's order cycle time. Logistics lead time is the time need to complete the process from goods to inwards to delivered product and the order cycle time is the period the customer is prepared to wait for delivery. A more conventional definition of lead time in the supply chain management realm is the time from the moment the customer places an order to the moment it is received by the customer. In the absence of finished goods or intermediate (work in progress) inventory, it is the time it takes to actually manufacture the order without any inventory other than raw materials.

Supply chain is that which deals with lead time. A supply chain is a network of facilities that procure raw materials, transform them into intermediate goods and then final products, and deliver the products to customers through a distribution system. Supply chain management (SCM) is the process that is used by a company to ensure that its supply chain is efficient and cost effective. Ketkar and Vaidya (2012) define supply chain management as the management of the flow of materials, information and funds across the entire supply chain including the suppliers, producers, assemblers, distributors, warehouses, retailers, and the ultimate customers. According to Koprulu and Albayrakogl (2007), the ultimate goal of SCM is to meet customers' demand more efficiently by providing the right product, in the right quantity, at the right location, on the right time, and in the right condition.

A lean supply chain is the system that incorporates lean philosophy into the whole supply chain for the effective and efficient use of all resources. Lean supply chain ensures the exact amount of goods or services at the exact location within the time constraint. It has been noted by Martin Christopher et al. (2006) that the lean SCM is not just time-to-market for new product introductions but time-to-respond in terms of being able to meet the needs of time-sensitive customers. They also states that, supply chain strategy should be based upon a careful analysis of the demand and supply characteristics of the various product or markets served by a company. Mackee and Dr. Rose define lean SCM as an operational and strategic management philosophy that utilizes internet enabling technologies to effect the continuous regeneration of suppliers and service partner's network.

It is also important for a lean SCM to ensure the quality of the product through the whole supply chain network. Womack and Jones (1996) describe about incorporating Six Sigma Quality Control to lean management system in a way to bring production processes under control by reducing the defect rate and help foster the lean goal of flow in the supply chain encouraging continuous reexamination of the value stream for ways to eliminate waste. Now a day's customers always keen to get the better quality ones. The quality is therefore defined as a matter of how much valuable the product or service to the customer not to the manufacturers. Therefore quality management system is a big issue for the factories to sustain for a long time. Here in Bangladesh the garments factories are practicing at about 15 to 20 percent second quality product which is a big waste for the factories and it adversely affect the profit margin of the factory. And at the end of the day the factory is going to be a loser. So we have to put the glasses of the customer in defining quality.

Traffic light system is a way of reducing the quality faults. It works in a way the traffic light works in the transportation system. In this paper, the authors studied the traffic light system, a lean quality tool which was 
implemented in a garment industry in Bangladesh. The main goal of this paper is to show how traffic light system can reduce the quality faults, improve the lead time and thus strengthen the supply chain.

In the recent years, many literatures have written from various points of view and much research has been performed on lean manufacturing and lean tools and techniques for different industries. Recently in a quarterly report TECHNOPAC (2011) has stated about the lean approach to various processes, and managing resources for the apparel manufacturing industries. The report also described the various benefits of lean along and the management roles to sustain the system as well. Mahapatra and Mohanty (2007) studied about implementing lean manufacturing in continuous process industry. They also noted some tools and techniques that can be implemented in the factories. Farhana and Amir (2009) studied in the nine garment manufacturing companies which were selected purposively to ensure the best possible scenario of lean practices in Bangladesh. Abdulmalek and Rajgopal (2006) described a case where lean principles were adapted for the process sector for application at a large integrated steel mill. Value stream mapping was the main tool used to identify the opportunities for various lean techniques. They were also describe a simulation model that was developed to contrast the "before" and "after" scenarios in detail, in order to illustrate to managers potential benefits such as reduced production lead-time and lower work-in-process inventory. Ravikumar et al. (2011) also describes the application of Value Stream Mapping (VSM) and Single Minute Exchange of Die (SMED). Existing state production floor was modified by using VSM efficiently to improve the production process by identifying waste and its causes. Ripon and Paul (2011) worked with the layout design where existing layouts have been studied and then layouts are proposed to enhance the production system. Value Stream Mapping (VSM) was used as a basic lean manufacturing tool and some cellular manufacturing philosophies to find out the improved level of performance and productivity particularly in the garments sector of Bangladesh.

In the recent year various models have been proposed by different researchers about strengthening the supply chain. Koprulu and Albayrakogl (2007) developed an analytical hierarchy process (AHP) model that an apparel company can use for the selection of supplier. In the apparel sector now a day, demand is becoming more unpredictable and the supply chain is becoming more uncertain to predict or forecast. Alper Sen (2008) described about the recent trends across the fashion supply chain in the US using industry-wide data, articles from business journals, industry reviews and extensive interviews with an apparel manufacturer in California, and a major US department store chain to describe the current operational practices and how the industry is restructuring itself during the transition, focusing at the apparel manufacture and retail segments of the supply chain. In this unpredictable situation many researchers like Christopher et al. (2006) acknowledged about the supply chain agility because it is concerned primarily with responsiveness. It is about the ability to match supply and demand in turbulent and unpredictable markets. In essence it is about being demand-driven rather than forecast-driven.

Though in many literatures on lean quality system, researchers have emphasized on mistake proofing system and a very few have addressed the traffic light system. Habidin et al. (2012) examined and then proposed a Structural Equation Model to study the relationship between Lean Six Sigma practices and organizational performance in order to improve the quality level in Malaysian automobile industries. Ratnayake et al. (2009) implemented cellular manufacturing with mistake proofing system in the industry for quality controlling where a team of operators focuses mainly on one part of the garment, helped when addressing most of the problems identified in the root cause analysis. A quarterly report of Technopac (2011) has stated about the importance of lean system in ensuring the quality of the product in garments industry.

This paper will show how traffic light system can reduce the quality faults, improve the lead time and thus strengthen the supply chain. The system was implemented at the X Composite Industry Ltd. But we are keeping the factory name as anonymous because the factory is not willing to ascribe it into this report. Data has been collected for several months before and after the system being implemented. The results are also shown here in this paper which tells us about the improvement of the productivity and quality level. Lean manufacturing is normally known to reduce the lead time. This paper will show the quality improvement in terms of lead time and supply chain because about $5 \%$ production capacity has been increased through quality improvement. We shall also look into some quantified benefits of lean manufacturing as well where the principles of lean were the prime mover.

The paper will consist of the following sections. The first part will present a brief about the tools and techniques that were implemented in a Composite Knit Industry Ltd. The second section will describe the 
current state situation and performance that is being achieved by the factory. The third section of the paper will represent the scenario after implementing the traffic light system. Finally after discussing the results and findings, it will draw conclusions by comparing the status before and after the traffic light system being implemented.

\section{Methodology}

The study was carried out in a Composite Knit factoryto improve quality \& production level and to reduce waste. A Kaizen process was performed to find the way of continuous improvement. The factory consists of 37 lines having a production capacity of about 15000 pieces of garments per day. Most of the orders are for polo t-shirt. The factory is located at the Hemayetpur, Savar, near Dhaka, The capital of Bangladesh. First the company was assessed and analysis was carried out to find the current state map. Then a training module was developed to train the different level of personnel including the workers, supervisors, line quality personnel, quality controllers, production people and management personnel. After being trained all the associated personnel the traffic light system has been implemented in a single production line as a pilot basis considering that the global change will be carried out if the situation goes better after the traffic light system being implemented than before. The paper will address several quality points including alter percentage, rejection rates, rejection from finishing section etc. By examining the existing and future quality state finally this paper explores the benefits of implementing traffic light quality system in terms of lead time, cost and thus the supply chain improvement.

Traffic light quality system works in a similar fashion the transportation traffic light system works. Like the transportation system it includes three quality signal cards: green, yellow and red. In the production line each worker is characterized by a card and the card is being hanged above his/her head. Green is for good quality, yellow is for warning condition and red stands for stopping the production due to quality fault. Seven piece quality checking system has been implemented and the quality controllers were instructed to check the quality status every two hours interval and collect data of each worker on a regular basis. When a worker produces quality product with zero defect, he or she is characterized by a green card. A worker who does a single fault out of the checked seven pieces, he or she is warned by a yellow card that indicates that he or she should be more careful about quality for the next time. But when any worker who does multiple faults, a red card is hanged above his or her head that indicates that this worker is producing several faults that should be corrected and an extra care should be taken to this worker. The extra care may be in a way that he or she should be trained for that operation or if there have any problem, could be solved. This is not a way of pushing the workers but to motivate them so that they are willing to do the quality at the first time they make it. Based on the performance the workers and the production lines are scored by a common scoring system. The system offers that, the best worker and the best line that scored highest should be honored by the management and some incentive should be given to them for their outstanding performance. The system also offers that, they should also be honored bybeing put a best quality badge for the whole month so that they could feel proud and all other workers could inspire to achieve the highest quality level.

\section{Current state}

First the existing situation is noted and the alter percentage is shown in the following chart. From the chart it is shown that the alter percentage is about twelve percentage.

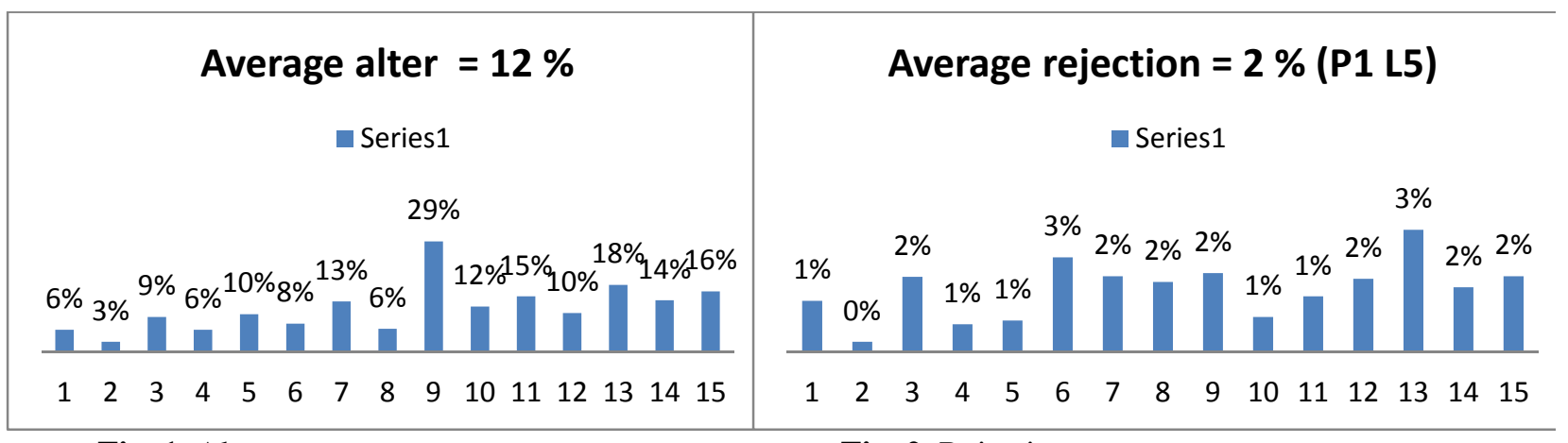

Fig. 1. Alter percentage at current state

Fig. 2. Rejection percentage at current state 
The rejection rate is also shown in another chart that indicates that the rejection rate is around 2-3\% averaging $2 \%$. Alter from finishing table is also collected and shown here in another chart. Within the thirty seven lines only eight lines were observed and the data was taken as a number of pieces for each line. The following figure shows that the average number of alter for each line is about 58 pcs per day.

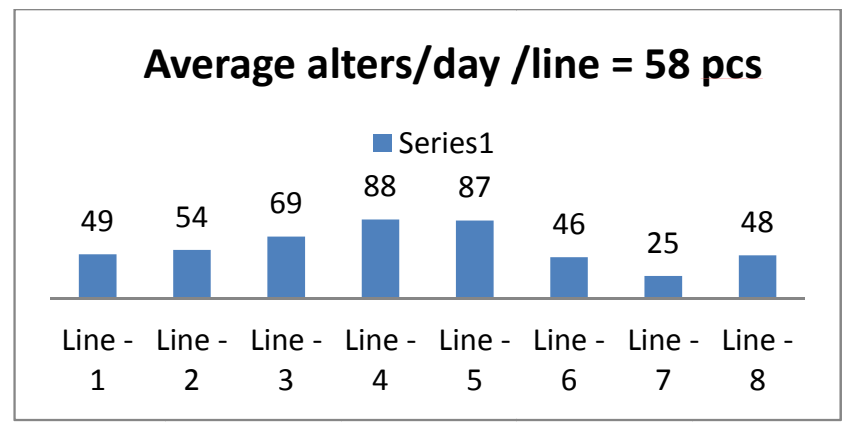

Fig. 3. No of alters from finishing section at current state

\section{Future state}

After analyzing the current state situation traffic light system was implemented in five floors and data has been collected for about several months. The alter percentage of each month for each floor is shown in the following chart. It clearly indicates that the alter percentage drastically goes down at a good rate and the average alter a rate becomes only about $4 \%$ from $12 \%$.

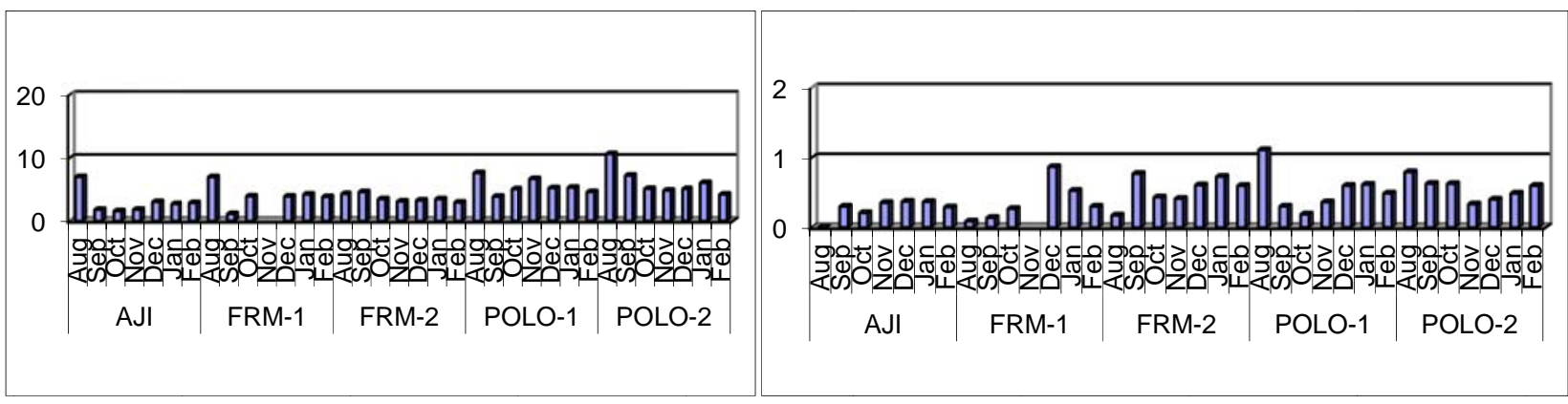

Fig. 4. Alter percentage at future state (average alters $=4 \%$ )

Fig. 5. Rejection percentage at future state (average rejections $=0.5 \%$ )

In a similar fashion for the whole five months period the rejection rate of each month for each floor was also collected which is shown in the following chart. The data clearly shows that it follows a downward trend and the average rejection rate goes down to only $0.5 \%$ from $2 \%$. Alter came back from finishing section was also stored and it is seen that alter at finishing area is also reduced drastically. After implementing the traffic light system the average number of alters per day per line at finishing section was reduced to only 22 pieces from 58 pieces with a reduction of 36 pieces of garments per day for each line. Monthly alter in pieces for each floor is shown below.

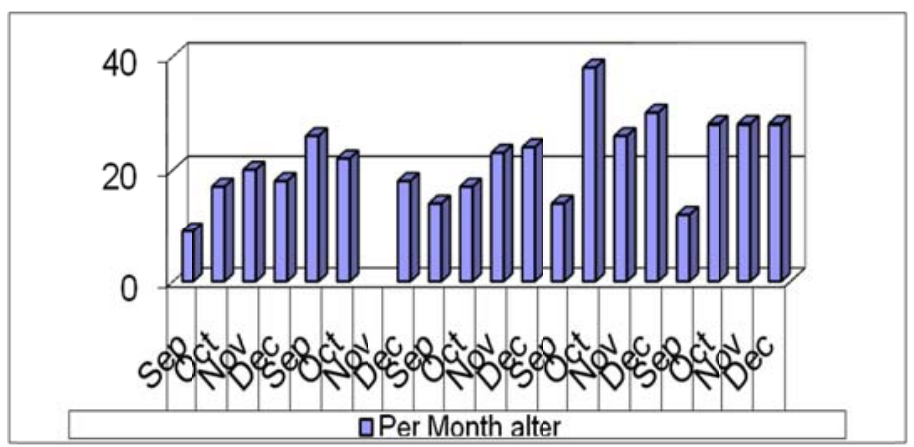

Fig. 6. No. of alters from finishing section at future state (Average no $=22$ pieces) 


\section{Findings (data based on the month of September, floor: FRM-2)}

\subsection{Days saved from alter}

At the table below data is provided for the FRM-2 floor which consists of 8 lines. We can see that about 17025 minutes or the production time of 946 garments were saved from the improvement of alter percentage. Considering the average daily production of 383 pieces per line per day, it can easily be said that about 0.31 day has been saved from the improvement from each line. It also resembles that, about 12 days production of a line has been saved for the whole factory from 37 lines.

\section{Table 1}

Days saved from alter percentage reduction

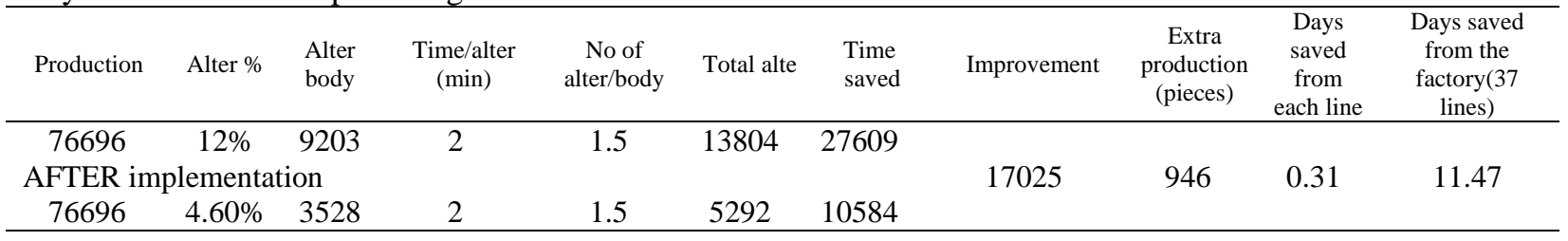

\subsection{Days saved from rejection}

From the improvement in the rejection area it is seen that 1150 pieces garments were saved from the 8 lines of FRM-2 floor. That means about 0.38 day was saved for each line through the month and the total save was about 14 days (equivalent to one line) for the whole factory.

Table 2

Days saved from rejection percentage reduction

\begin{tabular}{ccccc}
\hline Production & $\begin{array}{c}\text { Rejection } \\
(\%)\end{array}$ & $\begin{array}{c}\text { Rejected body from 8 } \\
\text { lines }\end{array}$ & $\begin{array}{c}\text { Days saved from } \\
\text { each line }\end{array}$ & $\begin{array}{c}\text { Days saved from the factory } \\
\text { (37 lines) }\end{array}$ \\
\hline 76696 & $1.50 \%$ & 1150 & 0.38 & 14 \\
\hline
\end{tabular}

\subsection{Days saved from loss reduction due to alter rectification}

The improvement from the loss of alter that cannot be rectified was also significant. From the previous history it was seen that about $10 \%$ alters were failed permanently. From the table below, it is seen that about 567 pieces garments were saved from the 8 lines of FRM- 2 floor. Therefore, about 0.19 day from each line and about 7 days production of one line from the whole factory was saved.

Table 3

Days saved from loss reduction due to alter rectification

\begin{tabular}{cccccccc}
\hline Production & $\begin{array}{c}\text { Alter } \\
(\%)\end{array}$ & $\begin{array}{c}\text { Alter/m } \\
\text { onth }\end{array}$ & $\begin{array}{c}\text { Rejection } \\
\text { (\%) }\end{array}$ & $\begin{array}{c}\text { Rejected } \\
\text { body }\end{array}$ & $\begin{array}{c}\text { Saved } \\
\text { (pieces) } \\
\text { from 8 lines }\end{array}$ & $\begin{array}{c}\text { Days saved } \\
\text { from each line }\end{array}$ & $\begin{array}{c}\text { Days saved from } \\
\text { the factory (37 } \\
\text { lines) }\end{array}$ \\
\hline \multirow{2}{*}{76696} & $12 \%$ & 9203 & $10 \%$ & 920 & 567 & 0.19 & 6.85 \\
\hline
\end{tabular}

\subsection{Days saved from alters come back from finishing section}

From the improvement done in the finishing area it is clear that the total improvement from the 8 lines was 288pieces of garments which indicates that about 0.40 day production has been saved from each line with a total save of about 14 days (equivalent to one line) for the whole factory.

Table 4

Days saved from alters come back from finishing section

\begin{tabular}{|c|c|c|c|c|c|c|c|c|c|}
\hline $\begin{array}{c}\text { Rejection } \\
\text { (before) from } \\
\text { finishing/day/lin } \\
\text { e(pieces) }\end{array}$ & $\begin{array}{c}\text { Rejection (after) } \\
\text { from } \\
\text { finishing/day/line(p } \\
\text { ieces) }\end{array}$ & $\begin{array}{l}\text { Saved } \\
\text { quantity/ } \\
\text { day/line }\end{array}$ & $\begin{array}{l}\text { Monthly } \\
\text { save/line }\end{array}$ & $\begin{array}{l}\text { Time/Alter } \\
\quad \text { (min) }\end{array}$ & Alter/body & $\begin{array}{l}\text { Total } \\
\text { time to } \\
\text { repair }\end{array}$ & $\begin{array}{l}\text { Total } \\
\text { pieces } \\
\text { saved }\end{array}$ & $\begin{array}{c}\text { Days } \\
\text { saved } \\
\text { from each } \\
\text { line }\end{array}$ & $\begin{array}{c}\text { Days saved from } \\
\text { the factory ( } 37 \\
\text { lines) }\end{array}$ \\
\hline 58 & 22 & 36 & 900 & 2 & 1.5 & 2700 & 150 & 0.40 & 14 \\
\hline
\end{tabular}




\section{Results}

From the above tables we can realize that a significance change has been carried out from different quality parameters. At the table below the summary of the above improvements is given. Here all the improvements are shown in terms of days saved. Reckoning all the improvements from different parameters it is seen that about 1.35 days production was saved from each line and about 47 days production of a line was saved from the whole factory. Considering 25 production days per month, it clearly depicts that about 2 lines monthly production was saved from the whole factory. The figure below depicts it clearly that the monthly capacity before implementing the traffic light system was equivalent to 925 days production of one line for a month whereas after the system being implemented it reduced to 878 days with animprovement of 47 days production capacity.

\begin{tabular}{|l|c|c|}
\hline Current state $=925$ days & \\
\hline Future state $=878$ days & Days saved $=47$ days \\
\hline \multicolumn{2}{|l}{} \\
\hline
\end{tabular}

Considering the average daily production rate of 383 pieces of polo shirts, the total production saved from the factory was about 17875 pieces and taking $\$ 3.50$ as the average price of a polo shirt, the total savings in terms of money for the month of September comes $\$ 62,000$ or about $45,00,000$ BDT.

Table 5

Total days saved after implementing the traffic light system

\begin{tabular}{cccccccc}
\hline & $\begin{array}{c}\text { Days } \\
\text { saved } \\
\text { from alter }\end{array}$ & $\begin{array}{c}\text { Days saved } \\
\text { from } \\
\text { rejection }\end{array}$ & $\begin{array}{c}\text { Summery (equivalent to a line) taking existing 40\% efficiency } \\
\text { saved from alter } \\
\text { to rejection }\end{array}$ & $\begin{array}{c}\text { Days saved } \\
\text { from finishing }\end{array}$ & $\begin{array}{c}\text { Total } \\
\text { days } \\
\text { saved }\end{array}$ & $\begin{array}{c}\text { Daily } \\
\text { production } \\
\text { (pieces) }\end{array}$ & $\begin{array}{c}\text { Saved } \\
\text { production }\end{array}$ \\
\hline For 37 lines & 11.41 & 13.88 & 6.84 & 14 & 47 & 383 & 17875 \\
For each line & 0.31 & 0.38 & 0.18 & 0.40 & 1.26 & 383 & 482 \\
\hline
\end{tabular}

\section{Conclusion}

Traffic light system is a system that can be implemented in any garment manufacturing company and it will help to improve the quality status, reduced the cost, improve the lead time and thus strengthen the supply chain performance without increasing the resource.

In this study, Traffic light quality system was implemented in a garment manufacturing company and after being implemented, quality improvement result was calculated in terms of days saved through the improvement. We know save of days is nothing but increasing the lead time and the more the lead time the better the supply chain performance is. Eventually production capacity was increased and cost was also reduced.

Implementation of the traffic light system for the global change was also proposed to the factory management to get the ultimate benefit. But to do so, all the players in the whole supply chain should work together at the same pace.

From this study we have seen that after implementing the lean traffic light system the quality status was improved and thus supply chain was strengthen through the improved lead time. So it can be said that, it is an urgent for the factories to adopt lean in the supply chain.

\section{References}

Abdulmalek, F. A., \& Rajgopal, J. (2007). Analyzing the benefits of lean manufacturing and value stream mapping via simulation: A process sector case study. International Journal of production economics, 107(1), 223-236.

Chakraborttya, R.K., \& Paul, S.K., (2011). Study and implementation of lean manufacturing in a garment manufacturing company: Bangladesh perspective. Journal of Optimization in Industrial Engineering, 4(7), $11-22$. 
Christopher, M. (1998). Logistics and supply chain management: strategies for Reducing Costs and Improving Service. $2^{\text {nd }}$ ed., Financial Times/Pitman Publishing, London, p 168.

Christopher, M., Peck, H., \&Towill, D. (2006). A taxonomy for selecting global supply chain strategies. International Journal of Logistics Management, 17(2), 277 - 287.

Ferdousi, F., \& Ahmed, A. (2009). An Investigation of Manufacturing Performance Improvement through Lean Production: A Study on Bangladeshi Garment Firms. International Journal of Business and Management, 4 (9), 106-116.

Habidin, N.F., Yusof, S.M., Omar, C.M.Z.C., Mohamad, S.I.S., Janudin, S.E., \& Omar, B. (2012), Lean six sigma initiative: Business engineering practices and performance in Malaysian automotive industry. IOSR Journal of Engineering (IOSRJEN), 2(7), 13-18.

Ketkar, M., \& Vaidya, O. S. (2012). Study of emerging issues in supply risk management in India. ProcediaSocial and Behavioral Sciences, 37, 57-66.

Koprulu, A., \& Albayrakoglu, M. M. (2007). Supply chain management in the textile industry: A supplier selection model with the analytic hierarchy process. Proceedings of the Ninth International Symposium on the Analytic Hierarchy Process (ISAHP 2007). (C. Garuti (ed.)). Pittsburgh, PA: RWS Publications.

Mackee, R., \& Dr. Rose, D., (2012). From Lean manufacturing to supply chain: a foundation for change, Lean supply chain management in the fashion industries, Lawson Whitepaper, Website version (swe.lawson.com/.../lawson_whitepaper_2_a4_lowres.pdf)

Mahapatra, S.S, \& Mohanty, S.R. (2007). Lean manufacturing in continuous process industry: an empirical study. Journal Scientific and Industrial Research, 66 (January), 19-27.

Marudhamuthu, R., Krishnaswamy, M., \& MoorthyPillai, D. (2011). The development and implementation of lean manufacturing techniques in Indian garment industry. Jordan Journal of Mechanical and Industrial Engineering, 5(6), 527-532.

Mason-Jones, R., \& Towil, D. (1999). Total cycle time compression and agile supply chain. International Journal of Production Economics, 62(1/2), 61-73.

Ohno, T. (1988). The Toyota Production System: Beyond Large Scale Production. Productivity Press, Portland, Oregon, Productivity Press.

Ratnayake, V., Lanarolle, G., Perera, C., \& Marsh, J. (2009). Cellular lean model to reduce WIP fluctuation in garment manufacturing. International Journal of Six Sigma and Competitive Advantage, 5(4), 340-358.

Sen, A. (2008). The US fashion industry: A supply chain review. International Journal of Production Economics, 114 (2), 571-593.

Technopac (2007). A Quarterly Report on Lean Manufacturing - The way to Manufacturing Excellence, Outlook, (Website version).

Womack, J. P. (1990). Machine that changed the world. Scribner.

Womack, L., \& Jones, D. (1996). Lean Thinking. Simon Schuster Ed., New York. 


\section{Appendices:}

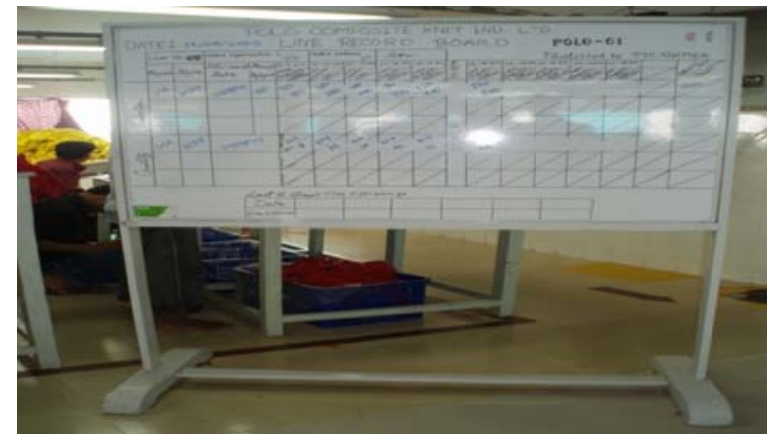

A. Line performance board:

\section{Summary Report (for 7 months)}

\begin{tabular}{|c|c|c|c|c|c|c|c|}
\hline FLOOR & MONTH & $\begin{array}{l}\text { Saving from } \\
\text { Alter }\end{array}$ & $\begin{array}{l}\text { Saving from } \\
\text { Rejection }\end{array}$ & $\begin{array}{l}\text { Loss Due To } \\
\text { Alter Rectify }\end{array}$ & $\begin{array}{c}\text { Alter Come } \\
\text { Back From } \\
\text { Finishing }\end{array}$ & G.TOTAL & G.TOTAL15\% \\
\hline \multirow{7}{*}{ AJI } & Aug & 22213 & 126616 & 33320 & 0 & 182149 & 27322.35 \\
\hline & Sep & 110149 & 280880 & 165223 & 195922 & 752174 & 112826.1 \\
\hline & Oct & 226045 & 586849 & 339068 & 218579 & 1370541 & 205581.15 \\
\hline & Nov & 250394 & 589161 & 375590 & 185703 & 1400848 & 210127.2 \\
\hline & Dec & 163577 & 436204 & 245365 & 195477 & 1040623 & 156093.45 \\
\hline & Jan & 185623 & 479028 & 278435 & 223910 & 1166996 & 175049.4 \\
\hline & Feb & 161713 & 453152 & 242569 & 173708 & 1031142 & 154671.3 \\
\hline \multirow{7}{*}{ FRM-1 } & Aug & 22213 & 126616 & 33320 & 0 & 182149 & 27322.35 \\
\hline & Sep & 57400 & 150083 & 86100 & 195922 & 489505 & 73425.75 \\
\hline & Oct & 191426 & 602640 & 287140 & 191923 & 1273129 & 190969.35 \\
\hline & Nov & & & & & & \\
\hline & Dec & 128843 & 262457 & 193264 & 213248 & 797812 & 119671.8 \\
\hline & Jan & 146746 & 423305 & 220119 & 191923 & 982093 & 147313.95 \\
\hline & Feb & 130107 & 404600 & 195160 & 147274 & 877141 & 131571.15 \\
\hline \multirow{7}{*}{ FRM-2 } & Aug & 34652 & 119952 & 51979 & 0 & 206583 & 30987.45 \\
\hline & Sep & 72041 & 175235 & 108062 & 175930 & 531268 & 79690.2 \\
\hline & Oct & 241593 & 682146 & 362390 & 218579 & 1504708 & 225706.2 \\
\hline & Nov & 236244 & 637063 & 354366 & 186592 & 1414265 & 212139.75 \\
\hline & Dec & 164213 & 396377 & 246320 & 181261 & 988171 & 148225.65 \\
\hline & Jan & 217495 & 498958 & 326242 & 197254 & 1239949 & 185992.35 \\
\hline & Feb & 207917 & 479808 & 311875 & 147274 & 1146874 & 172031.1 \\
\hline \multirow{7}{*}{ POLO-1 } & Aug & 19547 & 59976 & 29321 & 0 & 108844 & 16326.6 \\
\hline & Sep & 75793 & 238610 & 113691 & 175930 & 604024 & 90603.6 \\
\hline & Oct & 173232 & 668184 & 259849 & 121856 & 1223121 & 183468.15 \\
\hline & Nov & 85432 & 386862 & 128148 & 194970 & 795412 & 119311.8 \\
\hline & Dec & 119924 & 370353 & 179885 & 170598 & 840760 & 126114 \\
\hline & Jan & 135439 & 424510 & 203158 & 110940 & 874047 & 131107.05 \\
\hline & Feb & 131503 & 399840 & 197254 & 47219 & 775816 & 116372.4 \\
\hline \multirow{7}{*}{ POLO-2 } & Aug & 6219 & 66640 & 9329 & 0 & 82188 & 12328.2 \\
\hline & Sep & 39913 & 174623 & 59870 & 183926 & 458332 & 68749.8 \\
\hline & Oct & 167049 & 508409 & 250573 & 182784 & 1108815 & 166322.25 \\
\hline & Nov & 123653 & 437939 & 185480 & 182784 & 929856 & 139478.4 \\
\hline & Dec & 128065 & 445444 & 192098 & 182784 & 948391 & 142258.65 \\
\hline & Jan & 95502 & 364203 & 143253 & 120587 & 723545 & 108531.75 \\
\hline & Feb & 113859 & 306544 & 170789 & 57881 & 649073 & 97360.95 \\
\hline & & 4176373 & 12092520 & 6264563 & 4794270 & 28700344 & 4305051.6 \\
\hline
\end{tabular}

\section{B. Traffic light system:}

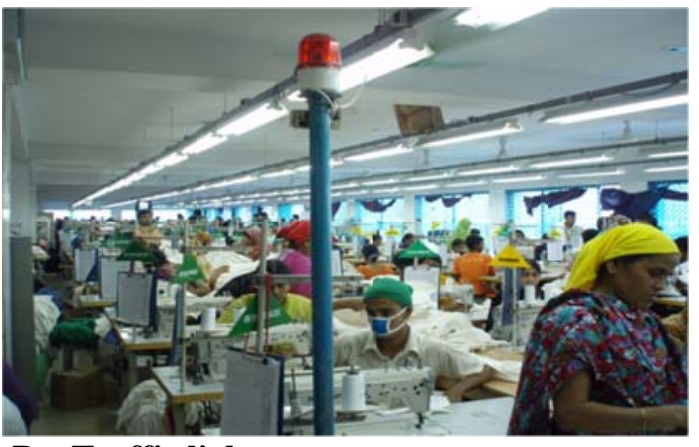


D. End line inspection report

\begin{tabular}{|c|c|c|c|c|c|c|c|}
\hline \multicolumn{8}{|c|}{ END LINE INSPECTION REPORT } \\
\hline & \multirow{3}{*}{$\begin{array}{c}\text { Date: } \\
\text { Defect Description }\end{array}$} & \multicolumn{2}{|c|}{ Style No: } & \multicolumn{2}{|c|}{ Line No: } & \multicolumn{2}{|c|}{ Unit: } \\
\hline & & & & me & & \multirow{2}{*}{ Total } & \multirow{2}{*}{ Comments } \\
\hline & & $9-11$ & $11-01$ & $02-04$ & $04-07$ & & \\
\hline \multirow{13}{*}{ ฮั่ } & Material / Printing Damage & & & & & & \\
\hline & Missing & & & & & & \\
\hline & Wrong size & & & & & & \\
\hline & Sainted & & & & & & \\
\hline & Wrong Style Code & & & & & & \\
\hline & Wrong Size Code & & & & & & \\
\hline & Cut Damage & & & & & & \\
\hline & Poor Stitching & & & & & & \\
\hline & Attach Wrong Placement & & & & & & \\
\hline & Main Label & & & & & & \\
\hline & Size Label & & & & & & \\
\hline & Wash Care Label & & & & & & \\
\hline & Flag Label & & & & & & \\
\hline \multirow{20}{*}{ 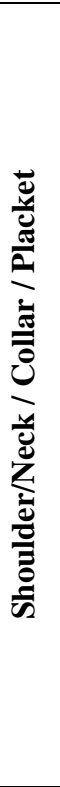 } & Out of Shape & & & & & & \\
\hline & Open Seam & & & & & & \\
\hline & Broken Stitch & & & & & & \\
\hline & Loose / Tight Stitch & & & & & & \\
\hline & Skip / Miss stitch & & & & & & \\
\hline & Needle Hole & & & & & & \\
\hline & Un- cut Thread & & & & & & \\
\hline & Oil / Stain Mark & & & & & & \\
\hline & Un-even seams / attach & & & & & & \\
\hline & Wrong SPI & & & & & & \\
\hline & Puckering & & & & & & \\
\hline & Waviness & & & & & & \\
\hline & Cut Damage & & & & & & \\
\hline & Materials Damage & & & & & & \\
\hline & Over Lapping & & & & & & \\
\hline & Shading & & & & & & \\
\hline & Shoulder Unbalance & & & & & & \\
\hline & Slanted & & & & & & \\
\hline & Front stripe not matched & & & & & & \\
\hline & Puckering - Placket & & & & & & \\
\hline \multirow{18}{*}{ 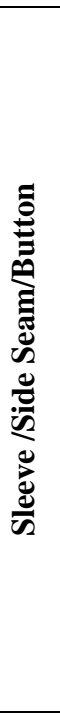 } & Out of Shape & & & & & & \\
\hline & Open Seam & & & & & & \\
\hline & Broken Stitch & & & & & & \\
\hline & Loose / Tight Stitch & & & & & & \\
\hline & Skip / Miss stitch & & & & & & \\
\hline & Needle Hole & & & & & & \\
\hline & Un- cut Thread & & & & & & \\
\hline & Oil / Stain Mark & & & & & & \\
\hline & Un-even seams / attach & & & & & & \\
\hline & Sleeve / Body Shading & & & & & & \\
\hline & Front / Back shading & & & & & & \\
\hline & Wrong SPI & & & & & & \\
\hline & Puckering & & & & & & \\
\hline & Waviness & & & & & & \\
\hline & Cut Damage & & & & & & \\
\hline & Materials Damage & & & & & & \\
\hline & Un match side seam & & & & & & \\
\hline & Un bal. sleeve Length & & & & & & \\
\hline & Total Alter & & & & & & \\
\hline & Total Spot & & & & & & \\
\hline & Total Reject & & & & & & \\
\hline & Total Check & & & & & & \\
\hline
\end{tabular}


E. In line checking form

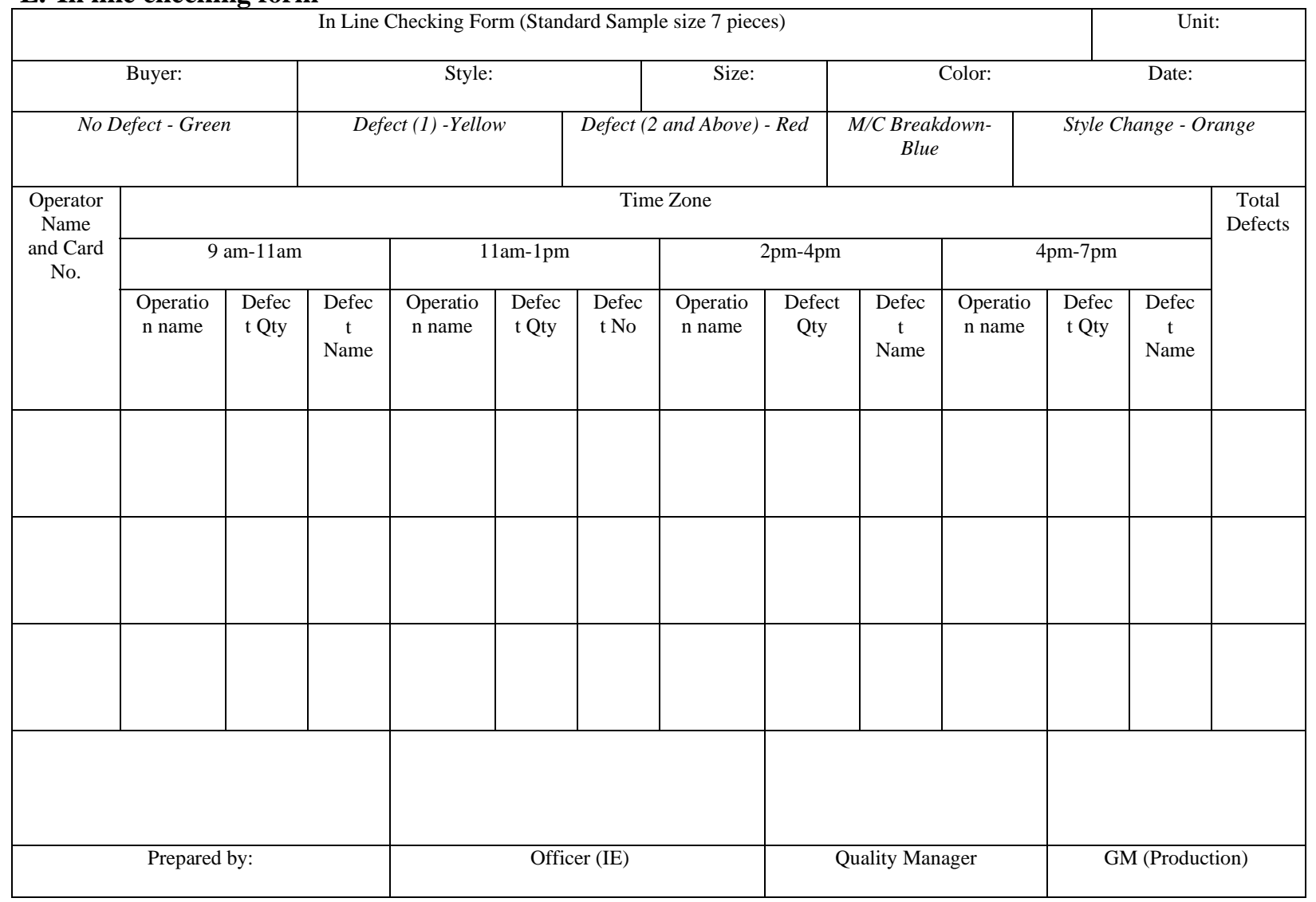


F. Operator quality performance sheet

\begin{tabular}{|c|c|c|c|c|c|c|c|c|c|}
\hline & & OPERATOI & QUA & TY $\mathrm{F}$ & FOR & ANC & HEET & & \\
\hline & & & aple & ze: 7 & s per & & & & \\
\hline & UNIT: & LINE: & & & RAT & & ID: & & JTH: \\
\hline No $D$ & $\mathrm{t}=$ Green, 1 & $\mathrm{ct}=$ Yellow & $\begin{array}{r}\operatorname{ark}, \\
\mathrm{F}\end{array}$ & blem & $\begin{array}{l}\text { bove } \\
\text { Blue }\end{array}$ & fect & ed, $\mathrm{S}$ & e Change = & range, $\mathrm{M} / \mathrm{C}$ \\
\hline Date & Buyer/Style & Operation & & & & Tim & & & Comments \\
\hline & & & $\begin{array}{l}9- \\
11\end{array}$ & $\begin{array}{l}11- \\
01\end{array}$ & $\begin{array}{c}02- \\
04\end{array}$ & $\begin{array}{l}04- \\
07\end{array}$ & Total & Signature & \\
\hline 1 & & & & & & & & & \\
\hline 2 & & & & & & & & & \\
\hline 3 & & & & & & & & & \\
\hline 4 & & & & & & & & & \\
\hline $\begin{array}{c}5 \text { to } \\
31\end{array}$ & & & & & & & & & \\
\hline
\end{tabular}

